\title{
The Role of SMEs in Tourism Development: an Industrial District Approach Applied to Killarney, Ireland
}

Ziene Mottiar

Technological University Dublin, ziene.mottiar@tudublin.ie

Theresa Ryan

Technological University Dublin, theresa.ryan@tudublin.ie

Follow this and additional works at: https://arrow.tudublin.ie/tfschhmtbook

Part of the Business Commons, and the Geography Commons

\section{Recommended Citation}

Mottiar, Ziene and Ryan, Theresa: The Role of SMEs in Tourism Development: an Industrial District Approach Applied to Killarney, Ireland. Thomas, R. and Augustyn, M.: Tourism in the New Europe: perspectives on SME policies and practices, Elsevier, 2006

This Book Chapter is brought to you for free and open access by the School of Tourism \& Hospitality Management at ARROW@TU Dublin. It has been accepted for inclusion in Books / Book chapters by an authorized administrator of ARROW@TU Dublin. For more information, please contact arrow.admin@tudublin.ie, aisling.coyne@tudublin.ie, gerard.connolly@tudublin.ie.

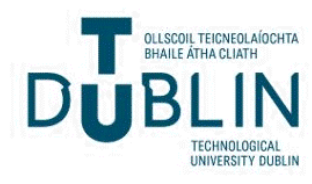


The role of SMEs in Tourism development: An industrial district approach applied to Killarney, Ireland

Ziene Mottiar, Lecturer Tourism Economics, School of Hospitality Management and Tourism, Dublin Institute of Technology, Dublin, Ireland

Theresa Ryan, PhD Student, School of Hospitality Management and Tourism, Dublin Institute of Technology, Dublin, Ireland. 
A primary concern for policy makers and academics alike has to be the development of tourism areas. Butler's (1980) article is concerned with this very issue and he develops a model which charts the development of a typical tourism area. There are many lessons to be learnt from this view of a path of development, but what is most interesting are the dynamics of this development. What is it that makes a tourism area move through the six stages? What is it that makes some resorts rejuvenate and others decline? Butler outlines these triggers as 'innovations in areas such as transportation, and in marketing as well as initiatives at the local and subsequently regional, national and international levels by developers' (Butler, 2000:290). This chapter briefly reviews some of the attempts that have been made at modelling tourism development and explaining its development, and concludes that an important stakeholder has been omitted from these models. It then goes on to use the industrial district approach to incorporate the vital role of small firms in the development of tourism areas.

Butler is not the only one to have developed tourism development models. Many other less well known theories have been developed and each has concentrated on the importance of a particular factor for the successful development of tourism areas. For example Gormsen (1981) highlights the importance of local participation and local control, Miossec (1976) emphasises the importance of transport hierarchies, speciality and co-operation, and Lundgren (1982) concentrates on the physical attributes of the area. More recent work by Ritchie and Crouch (2003) takes a much broader perspective and develops a model of tourism destination competitiveness. They concentrate on five broad 
areas including supporting factors and resources, core resources and attractors, destination management, destination policy, planning and development, and qualifying and amplifying determinants.

This brief overview of the literature which develops models of tourism development shows a glaring omission. What the existing models have in common is the focus on the tourist and resources and to a lesser extent the importance of local community involvement. A vital stakeholder in the tourism area and product has been ignored and that is the firms. That said it must be noted that in Ritchie and Crouch's (2003) grounded approach they have relied extensively on the views of industry in developing their model, yet the firms don't appear as an important element in the model. Lewis's (1998) work does accredit individual business owners and entrepreneurs for a great deal of the tourism development in the community and also notes the important role of community leaders but while this is identified as an issue in-depth analysis of this contribution is not undertaken.

It is in this vein of research that this chapter is concerned. Industrial district theory, developed in the economic geography literature, explains the economic success of an area by factors such as the geographical and sectoral concentration of predominantly small firms, strong inter-firm relations, and the existence of a social or professional milieu and high levels of innovation. The focus is on the firms but importantly rather than the individual firm it is the community of firms and the relationships between them which is of primary concern. This chapter investigates whether this type of approach is useful in 
explaining successful tourism development. Section one will outline industrial district theory, section two will discuss the relevance of industrial district theory to tourism and section three will present a case study of a successful tourism area in Ireland to evaluate whether it's success can be explained using industrial district theory. Comment will then be made on the usefulness of introducing this approach to the tourism development literature.

\section{What is an industrial district?}

Industrial district theory began in the late nineteenth century with the work of Marshall (1898) who was trying to explain the localisation (geographical concentration) of English industries such as pottery, cutlery and basket making. He outlined three main causes of localisation of industries: physical conditions, the patronage of court (i.e. a ready made market) and the deliberate invitation of rulers. The advantages of this localisation were then hereditary skills as 'the mysteries of the trade become no mysteries; but are as it were in the air, and children learn many of them unconsciously' (Marshall, 1898: 350), the growth of subsidiary trades and the use of highly specialised machinery. The principles and ideas developed by Marshall remain the basis of the literature on this topic almost a century later.

In the late 1970 s the theory of industrial districts was applied to an area in Italy which became known as the 'third Italy' (Pyke, Becattini and Sengenberger, 1992). These 
regions seemed to be growing faster than the rest of the country and surviving recessions more successfully (Brusco, 1982). In 1984 work by Piore and Sabel brought this concept back to English speaking audiences and subsequently there have been case studies of industrial districts conducted throughout the world. For example in Spain (Benton, 1990), Germany (Schmitz, 1990), the US (Saxenian, 1985, 1994), Brazil (Schmitz, 1993), Kenya and Zimbabwe (Sverisson, 1992), Korea (Cho, 1994), and India (Knorriga, 1994, Cawthorne, 1995). With the existence of industrial districts having been established, more recent literature has focussed on aspects of an industrial district and how it functions (for example Pilotti, 2000, Gottardi, 2000; Bertini, 2000).

The case studies of industrial districts have resulted in a list of common characteristics that constitute an industrial district. These characteristics facilitate identification of an industrial district but are also the features which explain the successful development of that region. These characteristics are discussed below.

\section{Geographical and sectoral concentration of firms}

Industrial districts usually comprise of a clearly defined area - a town, a valley or a region. There is sectoral concentration and this can be identified in two ways firstly in terms of firms producing the same good - for example there are more than 400 shoe firms in the Sinos Valley in Brazil (Schmitz, 1993), but also in terms of the components of the final product being concentrated in the area. In Sinos Valley 
'within a $50 \mathrm{~km}$ radius of Novo Hamburgo, the centre of the Valley, most inputs are produced: uppers, soles, heels, insoles, insocks, shanks, glues, nails, eyelets, dyes etc' (Schmitz, 1993:5).

The geographical and sectoral concentration of firms in an industrial district has implications for product development, innovation and inter-firm relations which will be discussed later.

\section{Firms are usually small}

Most case studies of industrial districts portray regions with small firms, in fact in many cases the firms are micro-enterprises- employing up to nine people. For example in Valles Oriental in Catalonia (Spain) two thirds of the firms employ between one and nine people (Benton, 1990:67), and in Emilia-Romagna in Italy 75 percent of the firms employ less than ten workers (Amin, 1989).

The size of the firm is important as it is this that makes the firms interdependent on each other and thus impacts on inter-firm relations.

\section{Strong inter-firm relations}

The relations between firms in an industrial district are not simply competitive in nature, although competition is still intense. They also incorporate co-operative and social and familial elements. Firms often engage in horizontal competition with firms producing the same product as them, and co-operate vertically with suppliers and customers. However 
horizontal co-operation also occurs. This creates a web of interfirm relations which is much more complex than just merely competition.

In an industrial district competition is primarily in terms of quality and innovation rather than cost. As discussed above these firms are interdependent, no one firm could survive on their own, and it is this that provides the impetus for co-operation. Few, if any, firms are involved in every stage of production and so they are reliant on others to be able to produce their final good. Thus co-operation is evident throughout the district and can be both formal and informal. Formal co-operation in Ikast, Denmark, occurs as the cooperative body Danikast, employers have 'organised buses to bring women to work from the surrounding areas, have built a dormitory for young women, and have collectively purchased raw materials' (Kristensen, 1990:). The geographical concentration of these firms and their willingness to co-operate has resulted in them overcoming some of the difficulties that small firms often experience.

Informal co-operation takes the form of for example sharing tools and machinery, joint marketing and joint research. One of the interesting findings in industrial district research is that co-operation is often not determined as that by the firms involved. Kristensen (1990:151) describes how one entrepreneur he recently interviewed was 'vehemently opposed to any formalised co-operation, yet later during the interview, an upholsterer looked in to tell him that "their new sofa" had appeared on the front cover of a furniture magazine. Together they had not only produced 
the sofa, but had worked together several nights a week for six months to develop it.'

And yet he didn't classify this as co-operation. Schmitz (1990:98) points out that there is probably a great deal of co-operation which is not strategically pursued but 'just happens in the course of transactions between firms and in the course of contacts between their staff in and outside the place of work'.

An important element in inter-firm relations is social and familial ties. Family members and former employees often establish firms in the same business or a spin off business locally and this adds another dimension to business relationships within the district. Kristensen (1990) studies the Durup furniture industry in Denmark and presents a 'story of fathers, brothers and sons, masters and apprentices, and involves the development of a genealogical tree where craft and family relations have become interwoven into 70 years of business history' (1990:149).

Similarly in the furniture industry in Co. Monaghan in Ireland one owner reported that fourteen of the sixteen people who he had worked with in his previous employment now all had their own firms in the area. 80 percent of the owners of wooden furniture firms in this area could be linked directly or indirectly to one of the oldest furniture firms in the area (Mottiar, 1998). This creates a network of owners.

Focussing on inter-firm relations rather than individual firms is an important part of the industrial district approach 'the single elements of the system flourish as a result of their 
interdependence; not because any one of them however competent, is capable of playing on the stage alone' (Amin, 1989:119-120). Their success is embedded in the group of firms within the area and how they relate to each other.

So it is clear that inter-firm relations are an important element in the success of these districts and that they represent a complex web of competition, co-operative and social and familial relations. Fundamental to this is the existence of a social or professional milieu which creates the trust required to encourage co-operation.

\section{Social or professional milieu}

This is perhaps one of the most unique elements of this concept. A social milieu and the embeddedness of firms mean that there is a close link between society and firms: the relationships between the actors in the economy are not purely economic (Schmitz, 1993) - the relationship constitutes more than the exchange of labour for wages. What this comprises of in summary is a strong community of individuals, families and firms which is bound together by a 'socio-cultural identity and trust' (Schmitz, 1993:26). The common values that the milieu creates serve both to the bind the community together and to set unwritten rules by which firms operate. The operation of an industrial district also

creates the possibility of punishing those who behave incorrectly, "chiefly by withdrawing the willingness to conclude future transactions with them and social disapproval' (Dei Ottati, 1994:531). 
What it is that binds the communities together has been often identified as a common background of belief - in Emilia Romagana, Italy, for example it was the fact that a high proportion of voters were Communist and in Sinos Valley in Brazil 'a strong community spirit developed in the region based on the common German heritage' (Schmitz, 1993:2728). The social milieu strengthens the links between firms, and as such increases the flow of information, and thus levels of innovation. It also encourages trust and as a consequence encourages inter-firm co-operation.

In some industrial districts there was no evidence of a social milieu but what was apparent was a professional milieu whereby being part of a professional community created a group identity similar to that resulting from belonging to the same ethnic group or having the same religious or political beliefs. In the professional milieu that was identified in the Monaghan furniture industry having worked together in another firm in the area created a network of professionals who knew each other and 'contact between owners of furniture firms ... occurs at church, socially, during occasional visits to one another's firms and at exhibitions and fairs' (Mottiar, 1998:206).

Trust is an important by-product of the social or professional milieux. It is important to note that this trust is

'not the type of trust based on idealism or naiveté, but a trust based on the realisation by specialists that they need each other, in such a way that they will also have to trust each other to some extent' (Knorringa, 1994, p.76).

According to Boschima and Lambooy (2002:291) 
'trust means easier access to knowledge, primarily from similar firms. Short distances not only facilitate the co-ordination of individual actors, they also play a role in institutionalization of behavioural rules and transfer of knowledge and learning'.

This has obvious implications for the continual development of the district.

A social or professional milieu creates a trust between firms and also results in a set of unwritten rules which govern not only social behaviour within the community but also business decisions. Again, industrial district theory challenges us to look at the whole, the group of firms rather than individuals. The relations between these firms and their embeddedness in the area creates a social and professional milieu which influences the way they operate and contributes to the overall economic success of the region.

\section{Innovation}

Strong inter-firm relations and the existence of a social or professional milieu encourage the flow of information and this leads to high levels of innovation in an industrial district. Marshall notes that

'inventions and improvements in machinery, in processes and the general organisation of the businesses have their merits promptly discussed: if one man starts a new idea, it is taken up by others and combined with suggestions of their own; and thus it becomes the source of further new ideas' (1898: 350).

In Prato, Italy, information on production techniques diffuse widely and rapidly, 'because owner-operators talk to one another, because families live in the same social context, and 
because apprentices move easily from one workshop to another' (Harrison, 1994, p.102). These are examples of incremental innovations which are encouraged by frequent face to face contact, close proximity which allows information to flow quickly and as a result of the trusting relationships that exist between firms.

Each firm gains from the new idea of others and in turn their ideas benefit others in the district. Pilotti (2000, p.122) states that places should be considered as 'a context in which learning processes and institutional variables are bound together with economic and social factors'. Using Nonaka's (1998) concept of "ba" which is like shared space, Pilotti says that knowledge is embedded within the district. Thus the development of knowledge, through the exchange of ideas encouraged by the social milieu, interdependence, co-operation and trust, is then 'not owned by any particular firm but by the district as a whole, it is one of its tangible productive assets' (Gottardi, 2000:54). This then contributes to the areas success.

The successful development of these many areas identified as industrial districts has been attributed to the dominance of small firms which are geographically and sectorally concentrated and their strong inter-firm relations which encompass co-operation and trust and often a social or professional milieu. The group of firms are creators of the regions success. How is this then relevant for tourism? 


\section{Relevance of industrial district theory to tourism}

Undeniably industrial district theory has been primarily concerned with explaining manufacturing success and has featured in a very limited way in the tourism literature. In her research Hjalager (1999) concludes that there is no reason why a tourism area couldn't be an industrial district. Furthermore Mackum (1998) shows that some of the factors identified in the manufacturing sector in the third Italy are also relevant for the discussion on the development of tourism. This is however the first known attempt to identify an industrial district in a tourism area.

Industrial district theory is relevant for the study of tourism for a number of different reasons. Firstly, because our unit of study in tourism is most often a defined geographical area, concepts that take this type of regional approach are useful. Secondly relations between tourism firms are often quite complex (this is exemplified in Mottiar 2004) and so the industrial district approach which looks at a variety of different elements in this relationship is beneficial. In particular from a rural or resort tourism perspective the idea of a social or professional milieu is fascinating as a way of analyzing the complex relations that exist in these tourism areas. Most importantly using this theory reasserts the importance of firms in the development of a region and so contributes significantly to a debate which has omitted this vital contribution.

Having outlined the industrial district concept and identified its relevance for tourism, section four will now apply this concept to a successful tourism area in Ireland to identify if it can be classified as an industrial district. Furthermore it will determine if this 
approach is useful in ascertaining which factors have led to the successful development of this area.

\section{Methodology}

This paper reports the findings of a case study undertaken into tourism development in Killarney, County Kerry in 2004. Information was collected using a process of triangulation employing a number of methods of data collection. Key informant interviews were conducted with representative's of: the Board of Fáilte Ireland (the Irish Tourism Board), the Kerry Branch of the Irish Hotel Federation, Killarney Chamber of Tourism and Commerce, Killarney Urban District Council, Cork/Kerry Regional Tourism as well as a local historian/public relations officer

The research also involved a survey of local tourism suppliers representing a variety of firms in the local industry. The research tool was a questionnaire which was administered by the researcher with the owner or manager of the firm. It took approximately 20 minutes to one hour to complete the questionnaire. Eighty one firms firms were surveyed. These firms represent approximately one third of all tourism businesses in Killarney. They were selected on a random basis although it was ensured that the sample was representative of the different sub-sectors that operate in Killarney. Snowballing was also used to identify potential interviewees. 
In addition, a detailed analysis of archived sources of information on tourism development in the area was carried out. The findings also include data gathered through field notes and observations made during the research period in Killarney.

\section{Does industrial district theory explain success in Killarney tourism?}

Killarney town is situated in county Kerry in the southwest corner of Ireland. Although traditionally a market town, Killarney owes its growth primarily to the successful development of tourism. It is the oldest tourism centre in Ireland and its tourism dates back to the 1750s when Thomas Browne $4^{\text {th }}$ Viscount of Kenmare funded the building of an inn and a hotel to cater for the first intrepid travellers. Killarney is renowned both nationally and internationally as a significant tourism area in Ireland and tourism is now Killarney's staple industry (Killarney Development Plan, 2003). After the main cities of Dublin, Galway and Cork it is the next most popular tourism destination in Ireland and this is despite the fact that it is relatively inaccessible, is just a small town and relies primarily on natural attractions. While Killarney is famed for its beauty and for the magnificence of its scenery, and its environment has an intrinsic value as an important tourism asset, there are many other factors which have had an important role in the successful development of its tourism industry.

Industrial district theory provides a theoretical and conceptual base and a general framework for examining the dynamics of tourism in Killarney. This section reviews this 
approach in an effort to explain why Killarney has succeeded in developing a thriving tourism industry.

\section{Geographical and sectoral concentration}

Killarney is far removed from centres of high population density. The nearest major city, Cork is $86 \mathrm{kms}$ in distance while Dublin, the capital of Ireland is $345 \mathrm{kms}$. The town itself is quite small, with a population of 11,300 (Kerry County Council, 2003). The south and west of the town are surrounded by an expanse of rugged mountainous country and at the foot of these mountains nestle the world famous Lakes of Killarney and Killarney National Park

After Dublin, Killarney has more hotel rooms than any other tourism centre in Ireland (Kenny, 2004). There are 35 hotels in the town plus a thriving bed and breakfast sector (ibid). The physical geography of this area with a mountain range and lake, combined with historical development of the town means that Killarney is a clearly defined area. This area is dominated by tourism firms and there is a keen awareness in the town of the importance of tourism for the regions continued growth and success. Moreover, within this small area there are not only accommodation suppliers but also restaurants, pubs, jaunting cars (providing horse and buggy tours in Killarney), craft and gift shops, equestrian centres, boat and walking tours as well as a local transport museum. This shows sectoral concentration in terms of the number of tourism firms but also diversity in terms of the components of the overall tourist experience that is provided by different firms in the area. 


\section{Size of firms}

Tourism in Killarney is characterised by the existence of many small businesses each providing essential components of the overall tourism product. The majority of tourism firms are small in size employing less than twenty people. Figure 1 highlights how 49 per cent of those surveyed can be classified as micro companies, employing less than ten people and 78 percent employ fewer than 40 people.

\section{FIGURE 1 ABOUT HERE}

This has created an interdependence among these firms. For example most accommodation firms are reliant on the entertainment providing firms to create an attraction to encourage tourists to come, and on the other side firms supplying entertainment are dependent on accommodation suppliers having beds available so that tourists will come and access their products. Due to this interdependence firms can remain small and survive and the local tourist area can thrive.

It must be noted though that there are a few large family hotel firms in the area. In 2002 four local families owned 48 percent of 3, 4, and 5 star hotel rooms in the area (Kenny, 2004). This creates a picture quite different to that of an area dominated by microenterprises. These four families have played a significant role in the development of 
Killarney as a tourism destination. What is interesting to note though is that in the main the families have expanded their core business (be it accommodation or entertainment) by establishing new premises or products rather than encroaching on the business of others by providing a new service. It is this that has allowed, and even facilitated, the parallel development of small firms in the area. Many small firms in the area have been able to develop and thrive as a result of the success of the larger, family run businesses. The larger hotels have the resources to market the area and attract tourists while still relying on the small firms to supply a 'seamless' product to their customers through the provision of rented bicycles, walking tours, boat rides, horse riding, jaunting cars rides as well as providing a broad range of places to eat and shop in the town. Through the vertical development of a core product (accommodation and entertainment), these families have encouraged the development of the area in general, and in particular the development of a range of complimentary products provided by the smaller firms. The interdependence of the firms as well as the focus on core business by the larger firms has been an important element in the region's development.

\section{Strong inter-firm relations - Competition and co-operation}

Competition and rivalry is intense between local tourism businesses in Killarney. $70 \%$ of respondents claimed that their main competitors are located in Killarney while only $2 \%$ see themselves competing with businesses at a national or an international level.

Despite this intense rivalry, there is strong evidence of co-operation between local businesses. When asked directly if firms in Killarney co-operate with each other, the 
majority of respondents were adamant that no co-operation took place. However, on closer inspection it is apparent that co-operation between firms takes place on a regular basis. The reason for this contradiction is that much of the co-operation takes place on an informal basis, between people who know each other well, and as a result it is not regarded as co-operation by respondents. This corresponds with the findings discussed in section 1 in other industrial districts. Confirmation of the existence of co-operation existed in a number of ways; there is evidence of vertical co-operation where businesses offering different products recommend each other to tourists. Co-operation with local tour operators and bike rental firms allows hotels to offer extensive and seamless services to tourists within their hotel facility. In addition, there is evidence of horizontal cooperation where tourism operators, such as hotels, refer guests to other hotels when they themselves have full occupancy. In general there is a lot of, what some respondents termed, "good neighbourliness" whereby businesses loan equipment to each other and help out in emergencies.

Many businesses in Killarney are involved in co-operative marketing through local marketing groups such as Killarney 250 (a local initiative that was set up to celebrate 250 years of tourism in Killarney and also to re-brand the area as a tourism destination). In 1994, a number of larger businesses in the area came together to form Killarney of the Welcomes, a local marketing group. The initiative for this came from the concern of local businesses regarding the marketing of Killarney being undertaken by the national tourism authority. More recently, local hoteliers have formed KIC (Killarney Incentive and Conferencing) a marketing group set up to market Killarney as a destination for 
incentive and conferencing business. One business owner commented there is good networking between hotels in Killarney and this comes about through the realisation that everyone benefits from a co-ordinated approach'.

These types of intitiatives have played an important role in creating and sustaining Killarney's success. The natural beauty of Killarney has become a tourist attraction because initiatives by local firms working together to establish marketing groups have established a national and international brand and reputation for the area.

It is clear that much of the co-operation between businesses in Killarney happens on an informal basis. Many business owners are from Killarney and have grown up together while others have know each other for many years, in some cases as neighbours and in others through the broader national hotel network. Figure 2 shows how interaction between businesses comes about in Killarney. Family ties, neighbours, friends or work colleagues' are highlighted as key sources of interaction indicating the extent of informal networking in the area.

FIGURE 2 ABOUT HERE 
Killarney's tourism industry is characterised by the existence of a number of family run businesses. The strength and influence of these local families has played a key role in developing tourism in the area. As early as the 1700s, local landowning families such as the Earl of Kenmare and Herberts of Muckross were influential in the development of Killarney's tourism industry. It was these very landlords in fact, that encouraged an entrepreneurial pervasiveness throughout Killarney. The Earl of Kenmare not only actively developed the area himself through the development of roads and other infrastructure, but also encouraged tenants to develop their own holdings. McLysaght (1970) explains that the Earl of Kenmare's entrepreneurial spirit and goal to encourage visitors to the area were clear in his plans for the development of an inn in the town and in the extended leases and favourable terms offered to tenants who participated in developing Killarney for the benefit of visitors.

Many of the tourism businesses can be linked back through generations of local families. The majority of tourism firms in the area are Irish owned and $61 \%$ of the businesses that took part in the survey were owned by people from Killarney specifically. This family ownership can be seen across a range of businesses. Jaunting car drivers, known locally as Jarvey's, spoke of grandfathers and fathers starting the business and passing it down to family members through the generations.. Tour companies and hotel owners spoke of tracing their businesses back to the 1800s. Business owners spoke of how being involved in the local tourism industry either through family connections or through working for other local businesses had lead them to develop their own tourism business in the area. 
This involvement in tourism through the generations creates a network (although not in a formal sense) of people who have a history together, who's parent and grandparents knew each other and who in many cases have grown up together. This creates closer links between firms and owners and a clear involvement in Killarney, as to them it is something much more than just a place they happen to have a business in.

This connection to the place is evidently important for business owners with 54 percent of respondents saying that being from Killarney was important or very important in developing business relations with other firms (see figure 3). Respondents claimed that Killarney is 'very parochial and that you need to fit in or know people'. Another explained that to be accepted in Killarney you 'had to bring something of value to the town'. Being related to other entrepreneurs was also considered very/important by $66 \%$ of respondents: 'who you know or who you are related to is very important'. Belonging to a family involved in the industry was considered very/important by $67 \%$ of respondents. This was considered 'a sure way of being successful' as 'family businesses support each other'. Respondents spoke of how influential local family businesses are and one respondent declared that 'it is important to belong to the Killarney mafia'.

\section{Social and professional milieu}

As the literature shows a social or professional milieu often transgress business and social life in the area. The fact that tourism has existed in this area since the 1750s and that many of the firms have been passed down through generations creates a social milieu in the area. 


\section{INSERT FIGURE 3 ABOUT HERE}

An important source of contacts and social networks of business owners was identified as sporting clubs. Belonging to the Gaelic Athletic Association (GAA) was considered very/important by $51 \%$ of respondents while being involved in other sports clubs were considered very/important by $59 \%$ of respondents. The level of importance, respondents explained, depended on the business that you were involved in, for example in the pub industry involvement in sports and GAA would be very important. Membership of golf clubs was also considered an important factor by respondents as this allowed for networking and making contacts.

There is also evidence of a professional milieu in Killarney. Many of the managers of the larger hotels have known each other through involvement in the IHF (Irish Hotel Federation) and have managed the same hotels, throughout Ireland, at different times over the years, for example one prominent business man in Killarney spoke of how both he and the general manager of a large hotel in Killarney had managed a number of the same hotels over the years, in addition they had both held the position of President of the Killarney Chamber of Tourism and Commerce as well as being active members of both the the Kerry Branch of the IHF as well as the National branch. This is an example of the type of strong networking and interaction between many of the hotels and infuences the entire community of businesses in Killarney. A number of hotel managers are involved 
in the local Irish Hotel Federation (IHF), the Killarney Chamber of Tourism and Commerce as well as being involved at a national level in Fáilte Ireland (The Irish Tourism Board) and the national IHF and national tourism steering committes. In this way many of these owners and mangers are active on the national stage and form a strong national lobbying group.

\section{Innovation}

For much of its development, Killarney has relied on the natural beauty of the area and the friendliness of the people rather than on any particularly innovative approach to development. There have been however, a number of notable innovations by local businesses that have influenced development of tourism in Killarney.

In seeking to maintain market share in short-break domestic market, hotels have sought to extend the tourist season through the development of bespoke packages in order to alleviate the problem of seasonal peaks and troughs. Tourism in Killarney is characterised by hotels offering packages such as golfing breaks and family breaks for one or more nights. This has reacted to a perceived market need and succeeded in extending the tourism season.

Muckross house and national park are important attractions in the area. The house was acquired by the Irish state in the 1932 but remained closed to the public for three decades during which time no consensus was reached as to how the House might best be used. Through the initiative of local business people the house opened to the public in 1964 and 
is today managed by a Board of Trustees that comprises over 200 members, who share an interest in the preservation of the folklore and history of Killarney (http://www.muckrosshouse.ie/trustees.htm). Although not necessarily falling into the category of innovative actions this shows foresight and with reflection this was a vital move in terms of tourism development in the area.

An important element and communicator of innovation in industrial districts has been the flow of information within the industry and area. It is clear that this is evident in Killarney via groups such as the Killarney 250 and bodies such as the local Irish Hotel Federation and branch and the Chamber of Commerce whereby owners and managers interact with each other regularly. More informally information about what firms are doing flows through the personal networks of friends, colleagues, and family members as they discuss new occurrences in the industry and in their workplaces.

The tourism sector in Killarney cannot be classified as highly innovative although there are some indications of small levels of innovation and foresight among firms. It is notable that this is not unusual as a number of industrial districts identified in the literature do not appear to exhibit strong levels of innovation (for example Limmasol, (Murray, 1990); Santiago, Mexico (Wilson, 1992)).

\section{Conclusions}

It has been established that Killarney is a successful tourism area in Ireland and this research has shown that it has the characteristics of an industrial district. Furthermore the 
analysis undertaken in section four, using an industrial district conceptual framework, shows the importance of the local firms in this successful development. While the natural resources that Killarney is endowed with are a significant asset, there are other areas with similar advantages. Therefore the explanation has to involve more than natural resources. At each point in the development of Killarney entrepreneurs and small firms have played a vital role. In the early period of development in the 1750s Thomas Browne played a leading role in instigating tourism as a business in the area and encouraging others to develop products to sustain this industry. In the 1960s business owners showed incredible foresight in their campaign to ensure that Muckross House would remain a public asset, which attracts tourists, rather than being sold to private interests. This heritage house and garden remains a major tourist attraction in the area. More recently firms have worked together to market Killarney independently of the national marketing campaigns undertaken by Fáilte Ireland. At each point in the development of this area small firms and their owners have played fundamental roles to ensure the continued existence and successful development of this tourism destination.

In addition to these identifiable points in the historical development of the area tourism firms have also contributed to the successful development of this area by the way they operate on a daily basis. The interdependence between firms is critical. Tourism in Killarney is built around the provision of a number of traditional tourism products such as jaunting car rides, boat rides and guided tours, these are all provided by the smaller firms in the area. Thus the larger hotels are reliant on the survival of these firms and need their co-operation in order to, for example, attempt to extend the season. These types of 
relationships create a common vision and goal. Rather than just concentrating on what is good for their own particular firm, owners and managers by necessity have to think about the implications for others and how they may react to their actions, and thus the implications for the area as a whole.

This chapter has clearly shown that the industrial district approach is valuable for the tourist literature. It challenges us to look at the firms in a destination as a group and to pay heed to their embeddedness in the local area and how they inter-relate to each other. Furthermore it shows clearly that firms must be considered as a vital factor when analyzing and explaining successful tourism development. As such this chapter is a useful addition to the tourism development models literature. It also shows other clear avenues of research in terms of identifying tourism industrial districts, investigating interfirm relations using the industrial district framework and further studying the idea of professional and social milieux in the context of tourist destinations.

\section{Bibliography}

Amin, Ash, (1989) 'A model of the small firm in Italy' in Goodman, E and J Bamford with P Saynor, Small firms and industrial districts in Italy, pp.111-123. Routledge: London.

Benton, Lauren, (1990) 'The emergence of industrial districts in Spain: industrial restructuring and diverging regional responses' in Pyke and Sengenberger, 1990 
Industrial districts and local economic regeneration pp. 48-86. International Institute for Labour Studies: Geneva.

Bertini, S (2000). Endogenous development of local systems of SMEs: lessons from practical experience, in Belussi, F and Gottardi, G Evolutionary patterns of local industrial systems Ashgate: Aldershot pp.91-113

Boschma, R and Lambooy, J G (2000). Knowledge, Market Structure, and Economic Coordination: Dynamics of Industrial Districts Growth and Change, Vol. 33 pp.291-311\#

Brusco, Sebastiano, (1982). 'The Emilian model: Productive decentralisation and social integration'. Cambridge Journal of Economics, Vol. 6 pp.167-184.

Butler, R.W. (1980): The Concept of a Tourist Area Cycle of Evolution: Implications for Management of Resources. Canadian Geographer, xxiv, 1, pp. 5 -m12.

Butler, R.W. (2000): The Resort Cycle Two Decades on. In: Faulkner, B. Moscardo, G. \& Laws, E. (2000): Tourism in the 21st Century. Lessons from Experience. London: Continuum.

Cawthorne, P M, (1995). 'Of networks and markets: The rise and rise of a South Indian town, the example of Tiruppur's Cotton knitwear industry'. World Development_Vol. 23 No. 1 pp.43-56.

Cho, M R, (1994). 'Weaving flexibility: large-small firm relations, flexibility and regional clusters in South Korea' in Pedersen, P D, A Sverrisson and M P van Dijk 
Flexible Specialisation: The Dynamism of Small Scale Industries in the South pp.111127. Intermediate Technology Publications:London.

Dei Ottati, G, (1994). 'Trust, interlinking transactions and credit in the industrial district'. Cambridge Journal of Economics Vol. 18 pp.529-546.

Gormsen, E. (1981): The spatio-temporal development of international tourism: attempt at a centre-periphery model, in La Consommation d'Espace par le Tourisme et sa Preservation, CHET, Aix-en-Provence. Pp. 150-170

Gottardi, G. (2000) Innovation and the creation of knowledge in Italian industrial districts: A system model, in in Belussi, F and Gottardi, G. Evolutionary patterns of local industrial systems (Ashgate: Aldershot) 49-70

Hjalager, A, tourism destinations and the concept of industrial districts ERSA Conference, Dublin August 1999.

Kenny, T. (2004) Interview with Tony Kenny, Assistant Tourism Officer, Cork/Kerry Regional Tourism.

Kerry County Council, (2003). Submission to the Tourism Policy Review Group, Department of Arts, Sport \& Tourism. Kerry County Council. Tralee 
Killarney Urban District Council, (1995). Development Plan for the Town of Killarney 1995.

Knorringa, P, (1994). 'Lack of interaction between trader and producers in the Agra footwear industry' in Pedersen, P D, A Sverrisson and M P van Dijk, 1994. Flexible Specialisation: The Dynamism of Small Scale Industries in the South pp.71-83. Intermediate Technology Publications: London

Kristensen, Peter Hull, (1990). 'Industrial district

ts in West Jutland, Denmark' in Pyke, Frank and Sengenberger, Werner, 1990, 'Industrial districts and local economic regeneration' pp. 122-175. International Institute for Labour Studies: Geneva.

Lee, C J, 1995. 'The Industrial Networks of Taiwan's small and medium sized enterprises'. Journal of industry studies_Vol. 2, No. 2 pp.75-87.

Lewis, J.B. (1998): A Rural Tourism Development Model. Tourism Analysis, Vol. 2. pp. 91-105.

Lundgren, J.O.J (1982): The Tourist Frontier of Nouveau Quebec: functions and regional linkages, Tourist Review, 37 (2), pp. 10-16.

Marshall, Alfred, (1898). Principles of Economics. McMillan \& Co. New York. MacLysaght, E. (ed.) (1970, first published 1942): The Kenmare Manuscripts. Shannon: Irish University Press for the Irish Manuscripts Commission. 
Miossec, J.M. (1976) Elèments pour une Thèorie de l'Espace Touristique, Les Cahiers du Tourisme, CHET, Aix-en-Provence. Cited in: Pearce, D. (1995), Tourism Today, A Geographical Analysis, Second Edition, U.K., Longman Group Limited.

Mottiar, Z (1998) Unpublished thesis Industrial districts and industrial clusters compared: Applications to Ireland. Dublin City University

Mottiar, Z (2004) Islands of Power: small firms in Courtown, Co. Wexford Ireland. ATLAS conference Networking and partnerships in destination development and management Naples, Italy April 3-6

Murray, Robin, (1990). 'Flexible specialisation in small island economies: The case of Cyprus' in Pyke, Frank and Werner, Sengenberger, 1990,_Industrial districts and local economic regeneration. pp.255-277. International Institute for Labour Studies: Geneva.

Piore, M and C Sabel, (1984). The Second Industrial Divide: Possibilities for Prosperity. Basic Books: New York.

Pilotti, L (2000) Networking, strategic positionng and creative knowledge in industrial districts Human Systems Management Vol 19 Iss. 2 pp.121-134

Pyke, F, G. Becattini, and W. Sengenberger, (1992). Industrial districts and inter-firm co-operation in Italy. International Institute for Labour Studies: Geneva. 
Ritchie, J.R.B, and Crouch, G.I. (2003): The Competitive Destination, A Sustainable Tourism Perspective. U.K., CABI Publishing.

Saxenian, A, (1994)._Regional Advantage: Culture and Competition in Silicon Valley and Route 128. Harvard University Press: Cambridge

Saxenian, A, (1985). 'The Genesis of Silicon Valley' in Hall, P and A Markusen, Silicon Landscapes pp.20-34. Allen \& Unwin: Boston.

Schmitz, Hubert, (1993). Small Shoemakers and Fordist Giants: Tale of a Supercluster. Ids Discussion Paper 331.

Schmitz, Hubert, (1990). 'Industrial districts: Model and reality in Baden-Württemberg, Germany' in Pyke, Frank and Werner Sengenberger, 1990,_'Industrial districts and local economic regeneration', pp. 87-122. International Institute for Labour Studies: Geneva.

Wilson, F, (1992) Modern Workshop industry in Mexico: on its way to collective efficiency? Ids bulletin vol. 23 No. 3 pp.57-63. 
Figure 1: Number of Employees

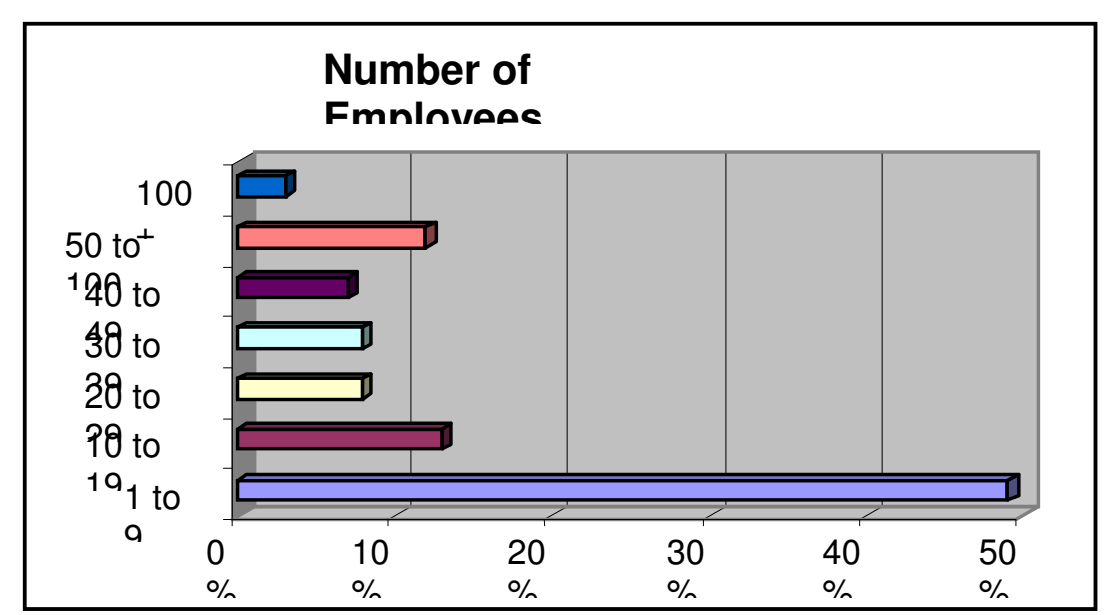




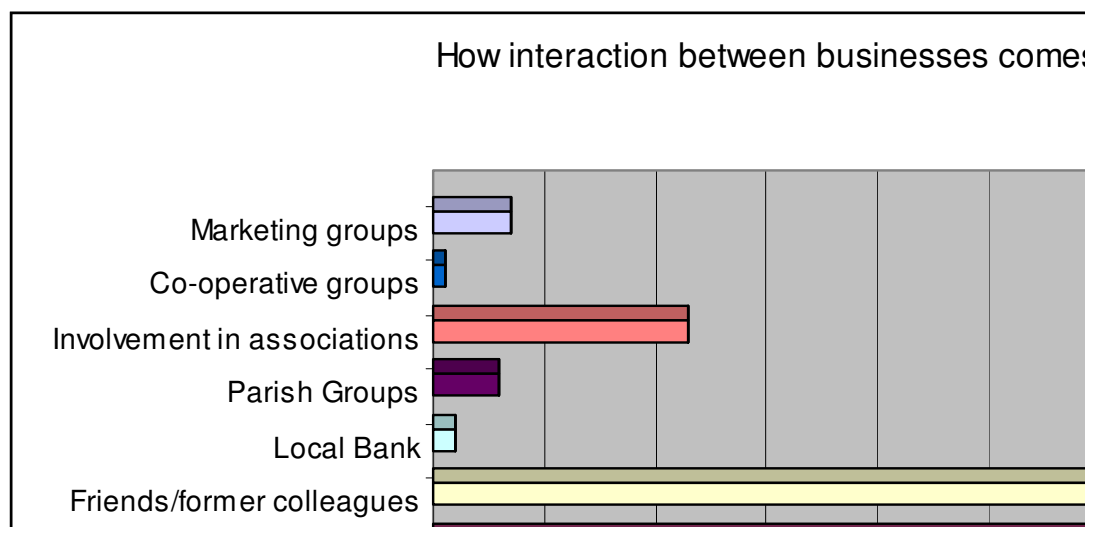

Figure 2. Source of Interaction between businesses 


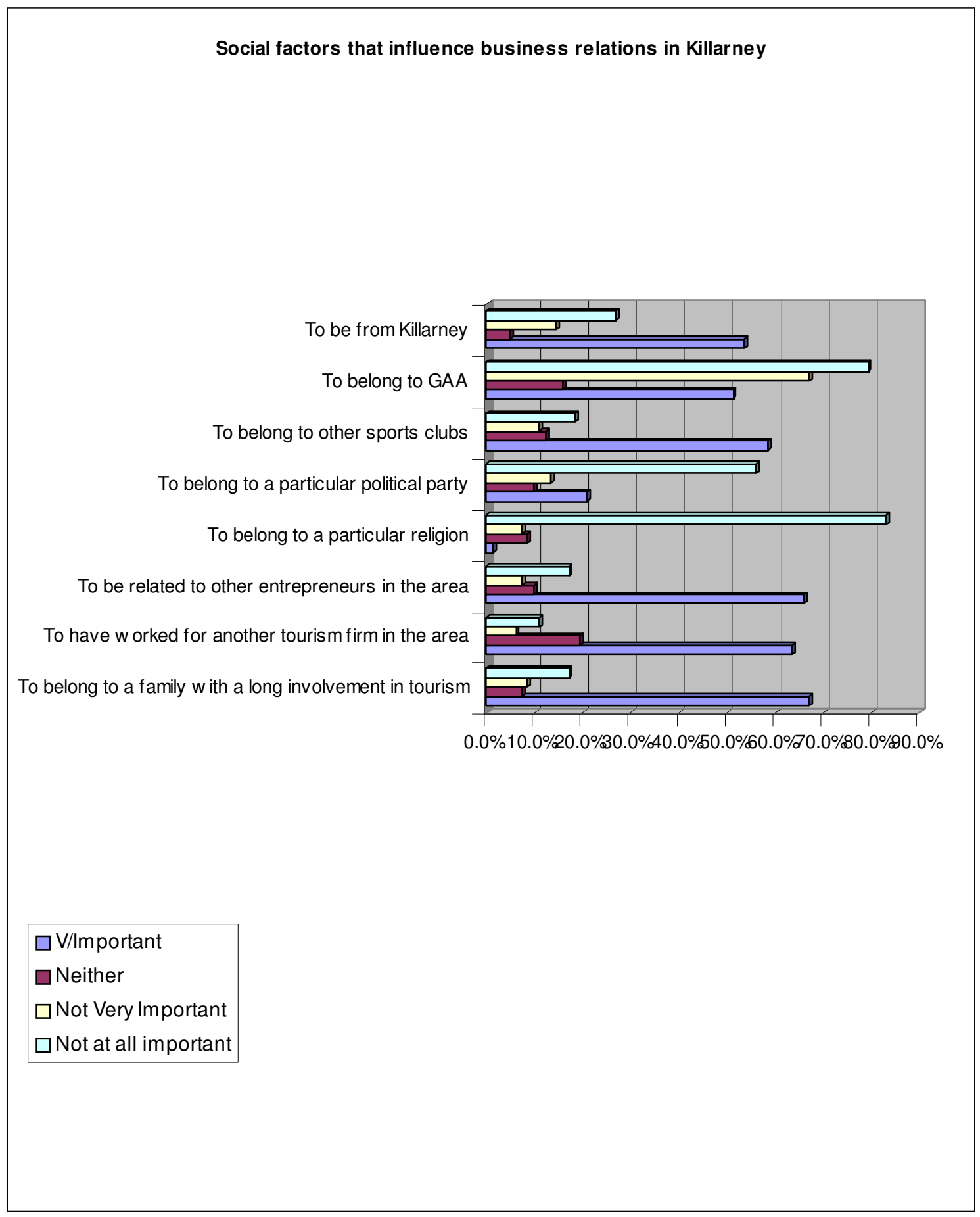

Figure 3: Social factors that influence business relations in Killarney 